\title{
TANK RISER SUSPENSION SYSTEM CONCEPTUAL DESIGN (U)
}

R. F. Fogle

September 15, 2002

Westinghouse Savannah River Company LLC

Savannah River Site

Aiken, South Carolina 29802 
This document was prepared in conjunction with work accomplished under Contract No. DE-AC09-96SR18500 with the U. S. Department of Energy.

\section{DISCLAIMER}

This report was prepared as an account of work sponsored by an agency of the United States Government. Neither the United States Government nor any agency thereof, nor any of their employees, makes any warranty, express or implied, or assumes any legal liability or responsibility for the accuracy, completeness, or usefulness of any information, apparatus, product or process disclosed, or represents that its use would not infringe privately owned rights. Reference herein to any specific commercial product, process or service by trade name, trademark, manufacturer, or otherwise does not necessarily constitute or imply its endorsement, recommendation, or favoring by the United States Government or any agency thereof. The views and opinions of authors expressed herein do not necessarily state or reflect those of the United States Government or any agency thereof.

This report has been reproduced directly from the best available copy.

Available for sale to the public, in paper, from: U.S. Department of Commerce, National Technical Information Service, 5285 Port Royal Road, Springfield, VA 22161, phone: (800) 553-6847, fax: (703) 605-6900

email: orders@ntis.fedworld.gov

online ordering: http://www.ntis.gov/help/index.asp

Available electronically at http://www.osti.gov/bridge

Available for a processing fee to U.S. Department of Energy and its contractors, in paper, from: U.S. Department of Energy, Office of Scientific and Technical Information, P.O. Box 62, Oak Ridge, TN 37831-0062,

phone: (865)576-8401,

fax: (865)576-5728

email: $\underline{\text { reports@ adonis.osti.gov }}$ 
Tank Riser Suspension System

Conceptual Dèsign (U)
WSRC-TR-2002-00362

Revision 0

APPROVALS
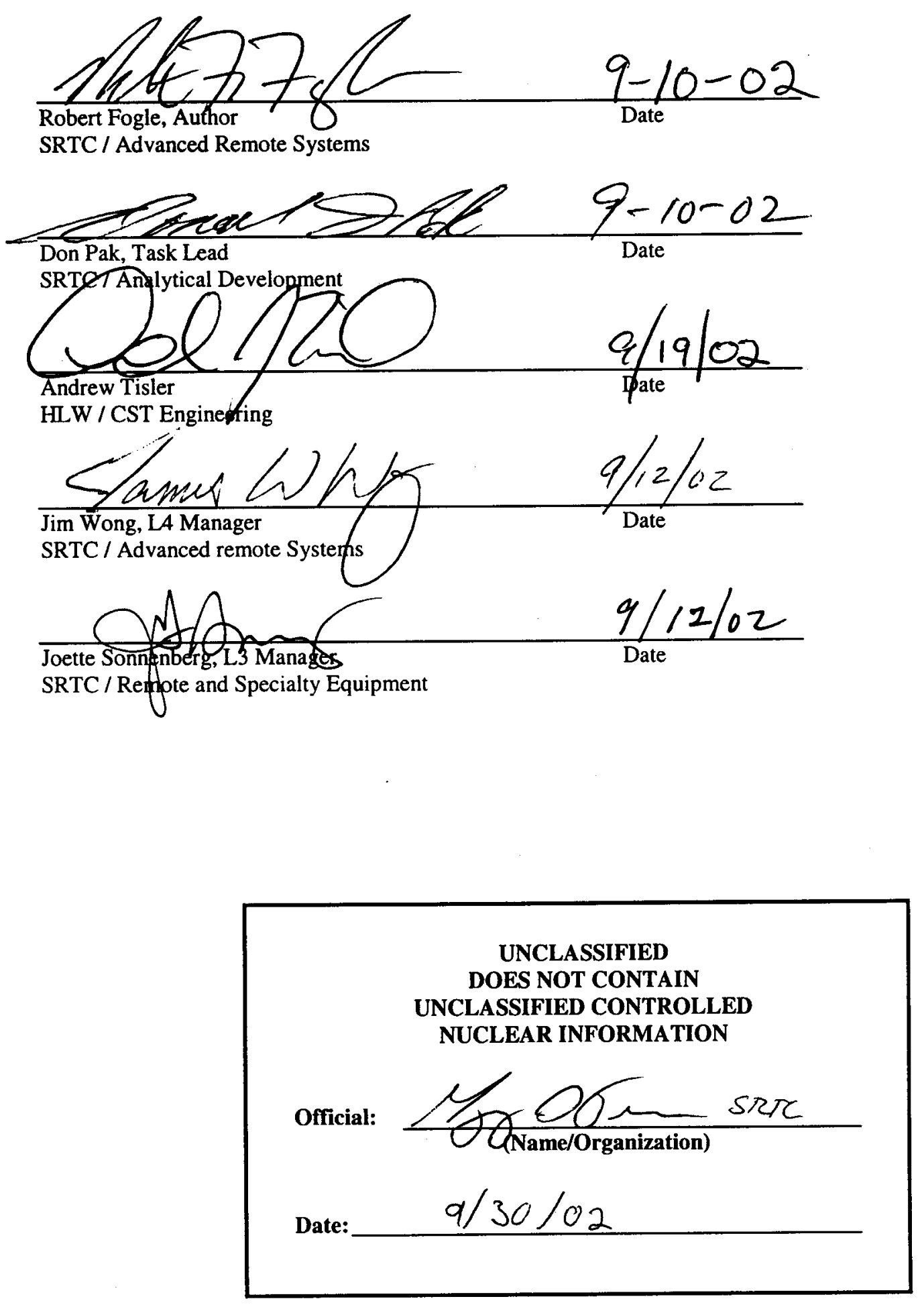

September 15, 2002

Page 3 of 27 


\section{TABLE OF CONTENTS}

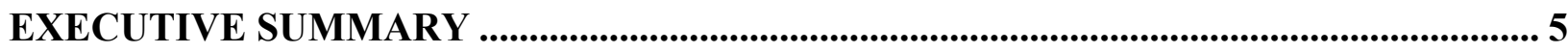

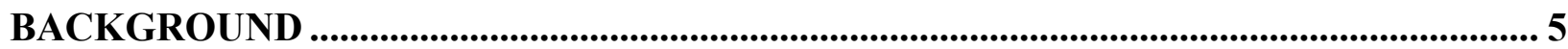

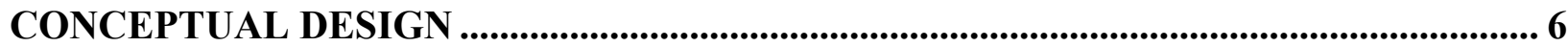

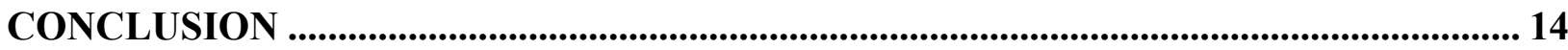

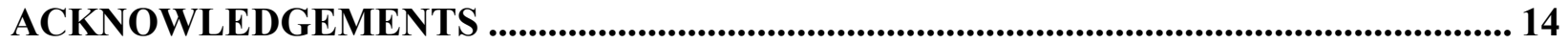

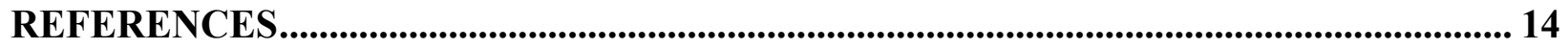

Appendix A

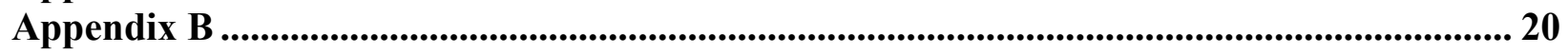

Appendix C ................................................................................................................................... 26

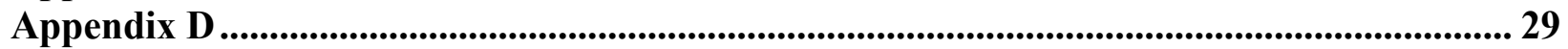

\section{TABLE OF FIGURES}

Figure 1: Rail installation in a riser ............................................................................................ 6

Figure 2: Riser with 4" tube installed ............................................................................... 7

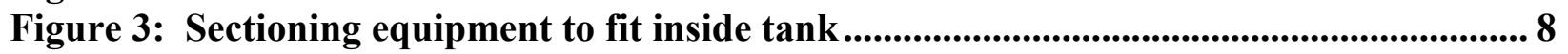

Figure 4: Failed equipment completely removed from tank ....................................................9

Figure 5: Inserting failed equipment into a tank using the guide rail system..................... 10

Figure 6: Lowering failed equipment into the tank......................................................... 11

Figure 7: Failed equipment sections hanging inside the tank................................................... 12

Figure 8: New equipment installed............................................................................................. 13 


\section{EXECUTIVE SUMMARY}

A team of engineers from High Level Waste (HLW), the Savannah River Technology Center (SRTC), and Project Engineering and Construction Division (PE\&CD) explored ways of more effectively utilizing the HLW tank's risers during waste removal and closure activities. Currently, some of the risers are being used to store failed and contaminated equipment. To make those risers available for tank operation, failed equipment must be moved out of the tank and relocated or disposed of appropriately. Disposing of contaminated equipment is a time consuming and expensive process. This report describes the Tank Riser Suspension System (TRSS). It will allow failed equipment to be stored inside of the tank while making riser space available for other tank process equipment. In addition, the TRSS will permit disposing of failed equipment in the tank as part of tank closure activities.

\section{BACKGROUND}

High-level radioactive liquid wastes are received, stored, and processed in large underground tanks at SRS. Five different types of tanks were built at SRS. Four of the five tanks are shown in Appendix A. Each type is unique and incorporates the lessons learned from past designs. There are risers on or integral with the top of each tank. Each tank type has a unique riser configuration as shown in Appendix B. The risers permit access to the tank and the tank's annulus. They are used primarily for the installation of pumps, cooling equipment, instrumentation probes, measuring devices, monitoring tools, and samplers. Examples of pumps used in the waste tanks can be found in Appendix C.

Type I Waste tanks have 15 risers, including the center riser. Type II Waste tanks have 28 risers. Type III Waste Tanks and Type IIIA Waste tanks have 40 risers. Type IV Waste tanks have 7 risers, including the center riser. The inside diameter (ID) of typical risers normally ranges between 23 " and 42 ", but some of them are very large. For example, the ID of the center riser of a Type IV tank is approximately 9 feet. A drawing of the cross section of a typical riser can be found in Appendix D.

There are a limited number of risers on a tank top. Efficiently utilizing them is crucial for successful waste removal and tank disclosure operations. Some of the risers are occupied by failed and contaminated equipment. To make those risers available for tank operation, the stored failed equipment must be moved out of the tank and disposed of appropriately. Disposing of contaminated equipment is a time consuming and expensive process. An alternative is the TRSS. It permits storing equipment inside of the tank while making the riser space available for other tank process equipment. This option will allow disposing of failed equipment in the tank during tank closure and may significantly reduce personnel radiation exposure and waste disposal costs. 


\section{CONCEPTUAL DESIGN}

The TRSS is based on the concept of hanging failed equipment with cables in a riser. The major components of the TRSS include the following:

1. A riser insert with rail guides

2. A clamp and rail attachment device

3. A lifting bail/guide block

4. A remotely detachable crane hook

The TRSS utilizes a riser insert with attached rails for hanging equipment as shown in Figure 1. The insert must be constructed of at least 2 sections with each part having a rail section. Figure 1 shows an insert consisting of 2 halves. The insert is installed into an empty riser using a crane. The rails extend into the tank and curve up to be parallel with the tank ceiling. In this way, the failed equipment can be stored away from the riser opening. By doing this, the riser is available for normal tank activities as well as for storage.
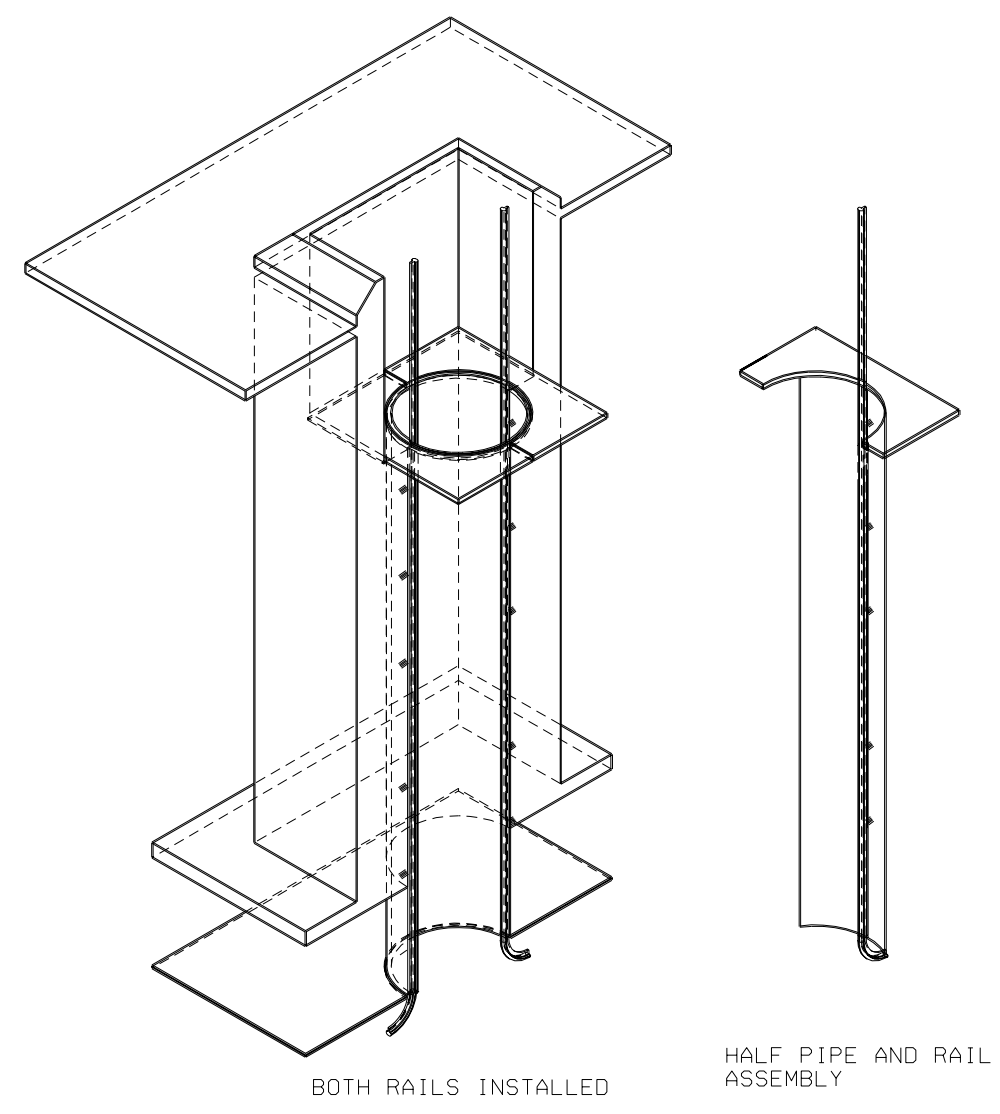

Figure 1: Rail installation in a riser 
If a pump or other equipment should fail in a riser, the first step is to remove the equipment from the riser. A clamp and rail attachment device or devices must be designed to grip the various sizes of equipment used in riser. As an example, Figure 2 shows a simple 4 -inch tube that is to be stored in the tank as failed and contaminated equipment. A clamping device is shown securing the failed equipment. The lifting bail/guide block assembly is attached to handle the failed equipment. The equipment is removed from the riser by using a crane.

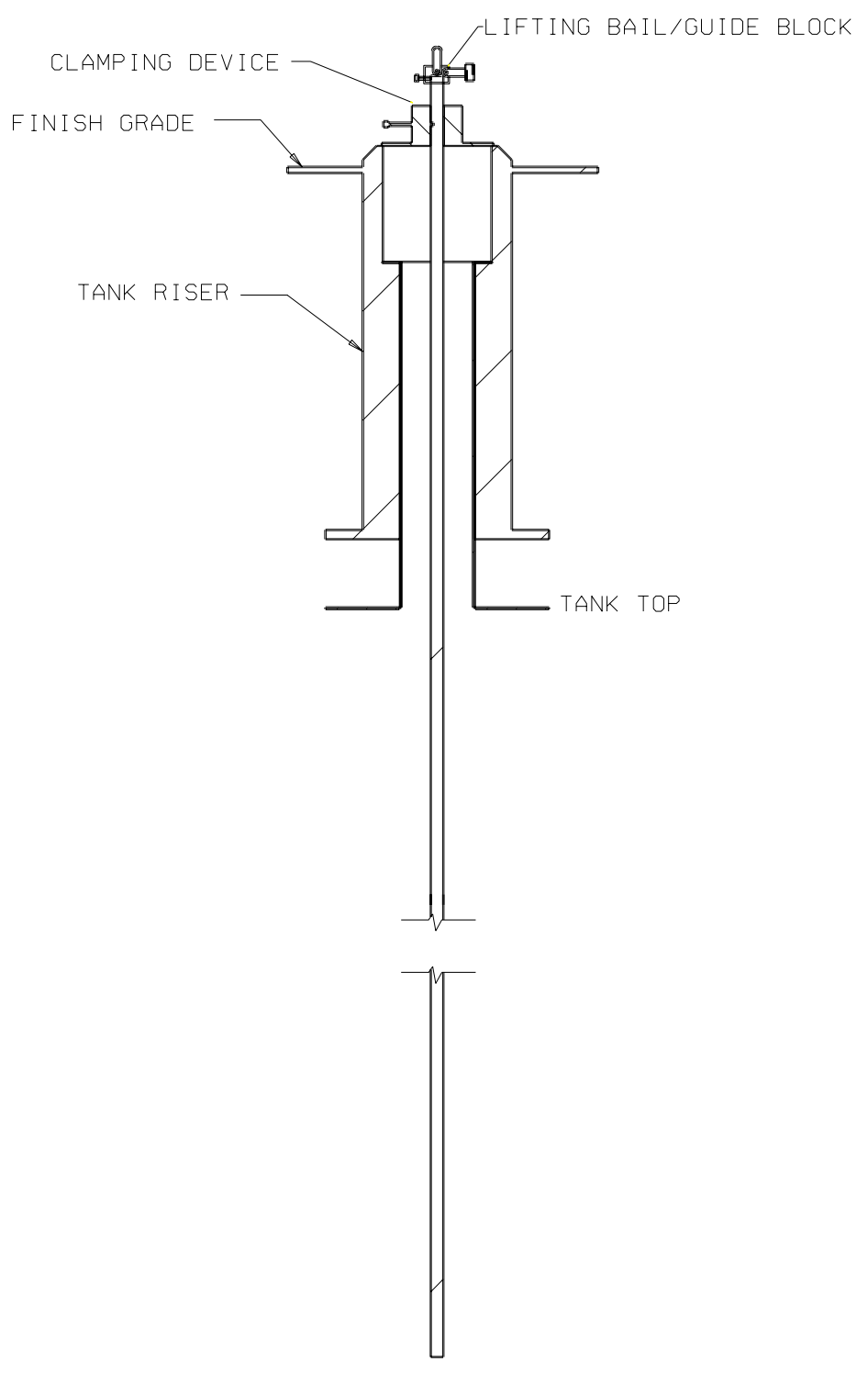

Figure 2: Riser with 4" tube installed 
The failed equipment cannot extend into the waste as this may cause an interference with tank closure activities. Equipment that is too long will have to be size-reduced. With the failed equipment held by a crane, the clamping device is loosened. The crane can then remove an appropriate length from the tank. The clamp secures the equipment remaining in the tank. The upper section of the failed device is cut as shown in Figure 3 while the lower section is held firmly in place by the clamp.

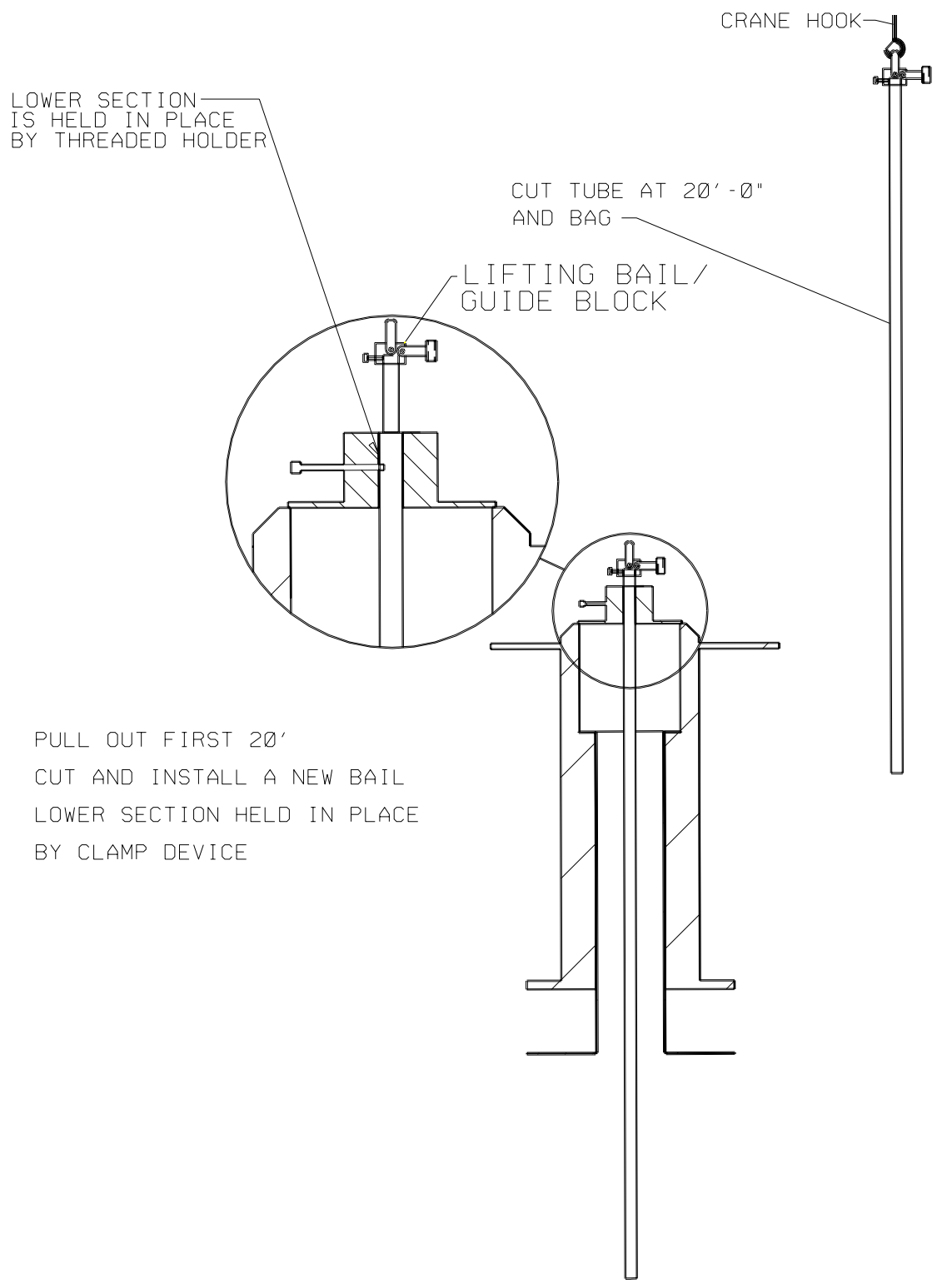

Figure 3: Sectioning equipment to fit inside the tank 
The removed section is monitored for radioactivity. It may or may not be stored in the tank based on the radiological survey. Assuming it is to be put back in the tank, it is temporarily stored on the tank top. The remaining section in the riser is then lifted out of the tank and is cut into smaller sections and surveyed. Once the equipment removal process is complete, the TRSS is installed in the riser as shown in Figure 4 . The sections of failed equipment are then ready to be lifted by the crane and returned to the tank.
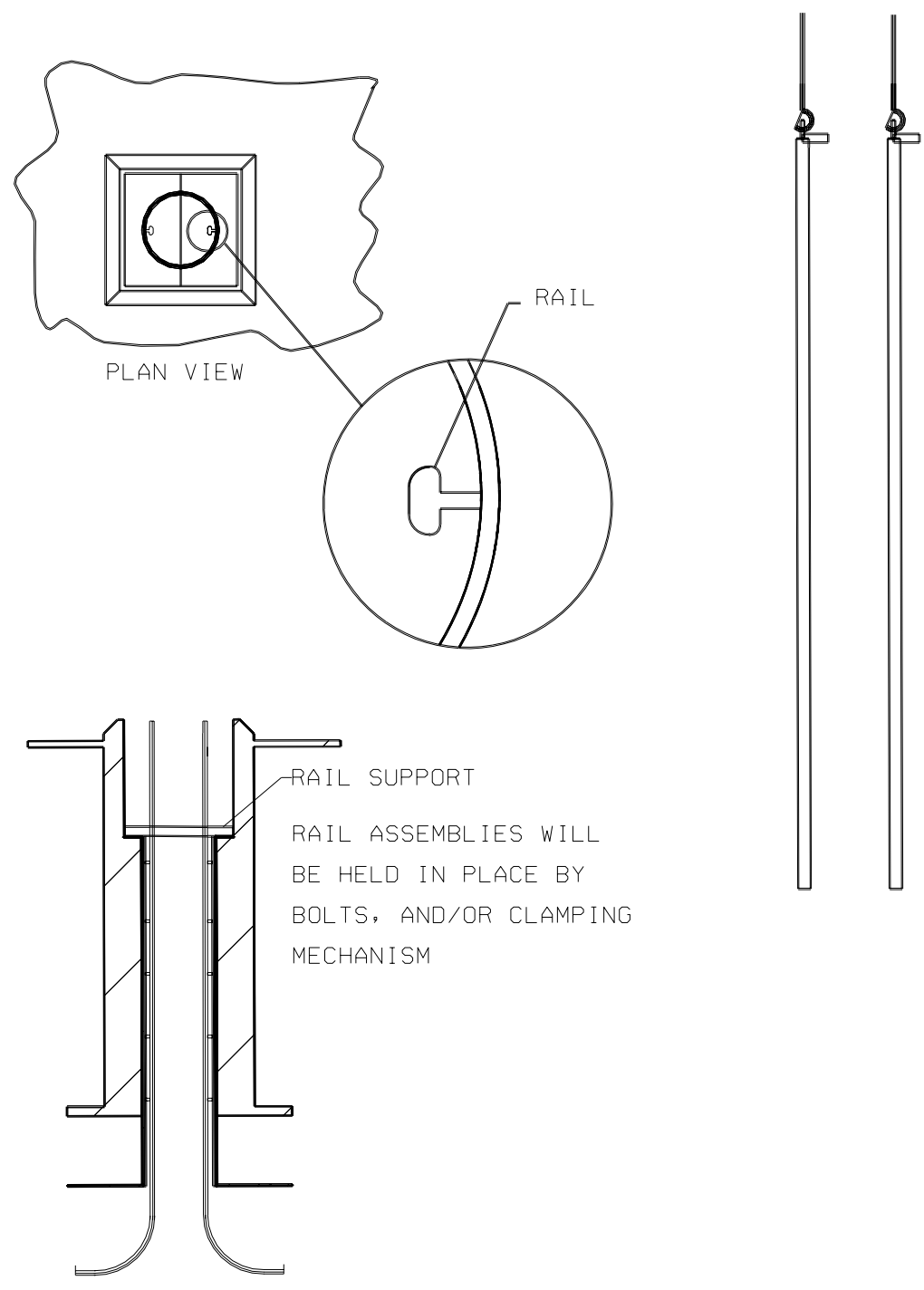

Figure 4: Failed equipment completely removed from tank 
Relocation into the tank will require a crane hook with a remote de-coupling capability as shown in Figure 5. The equipment to be returned is positioned onto the guide rail and lowered into the tank's riser.

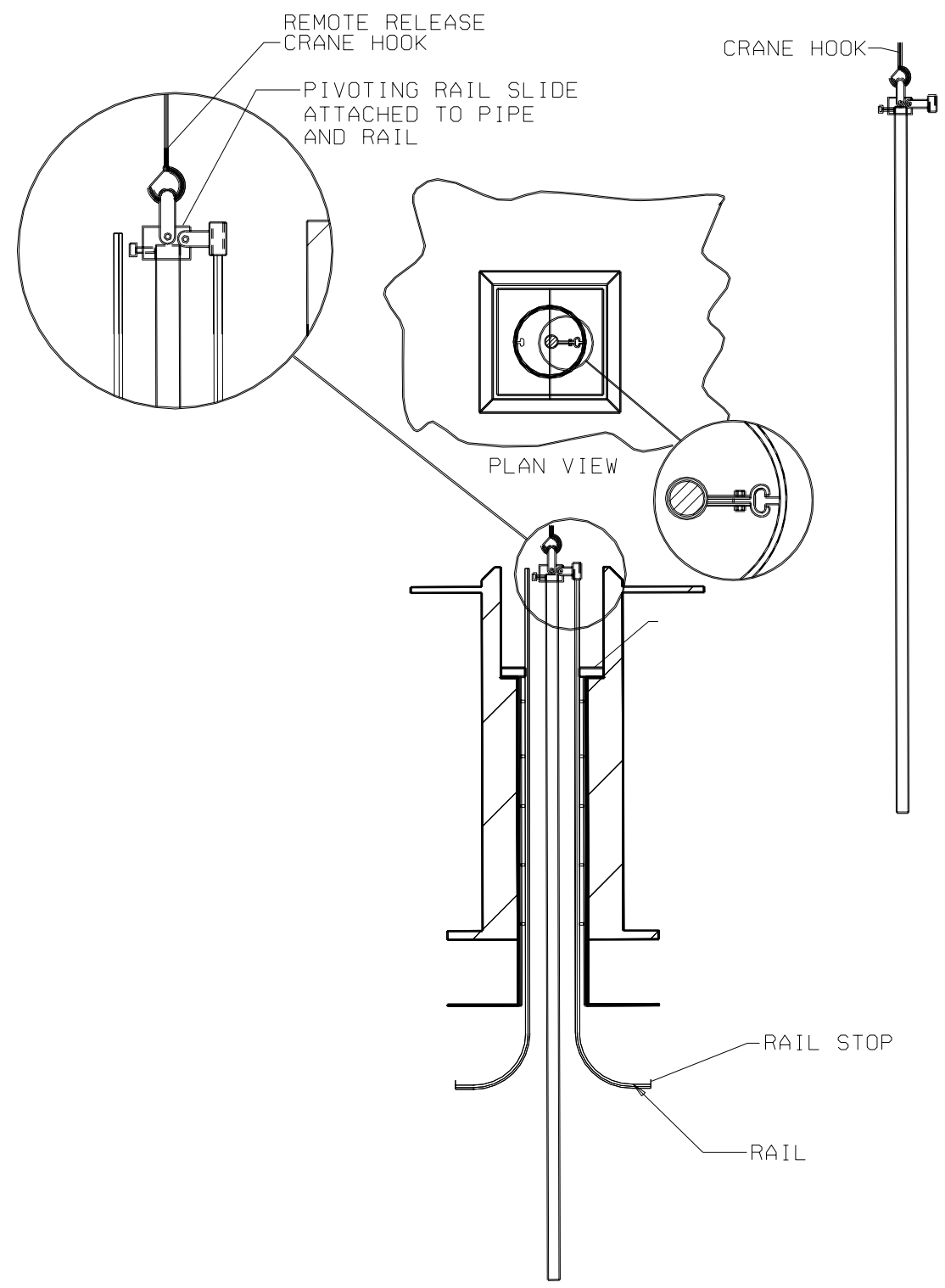

Figure 5: Inserting failed equipment into a tank using the guide rail system 
The guide block must be hinged to allow the equipment to transition the curved part of the TRSS rail as shown in Figure 6.

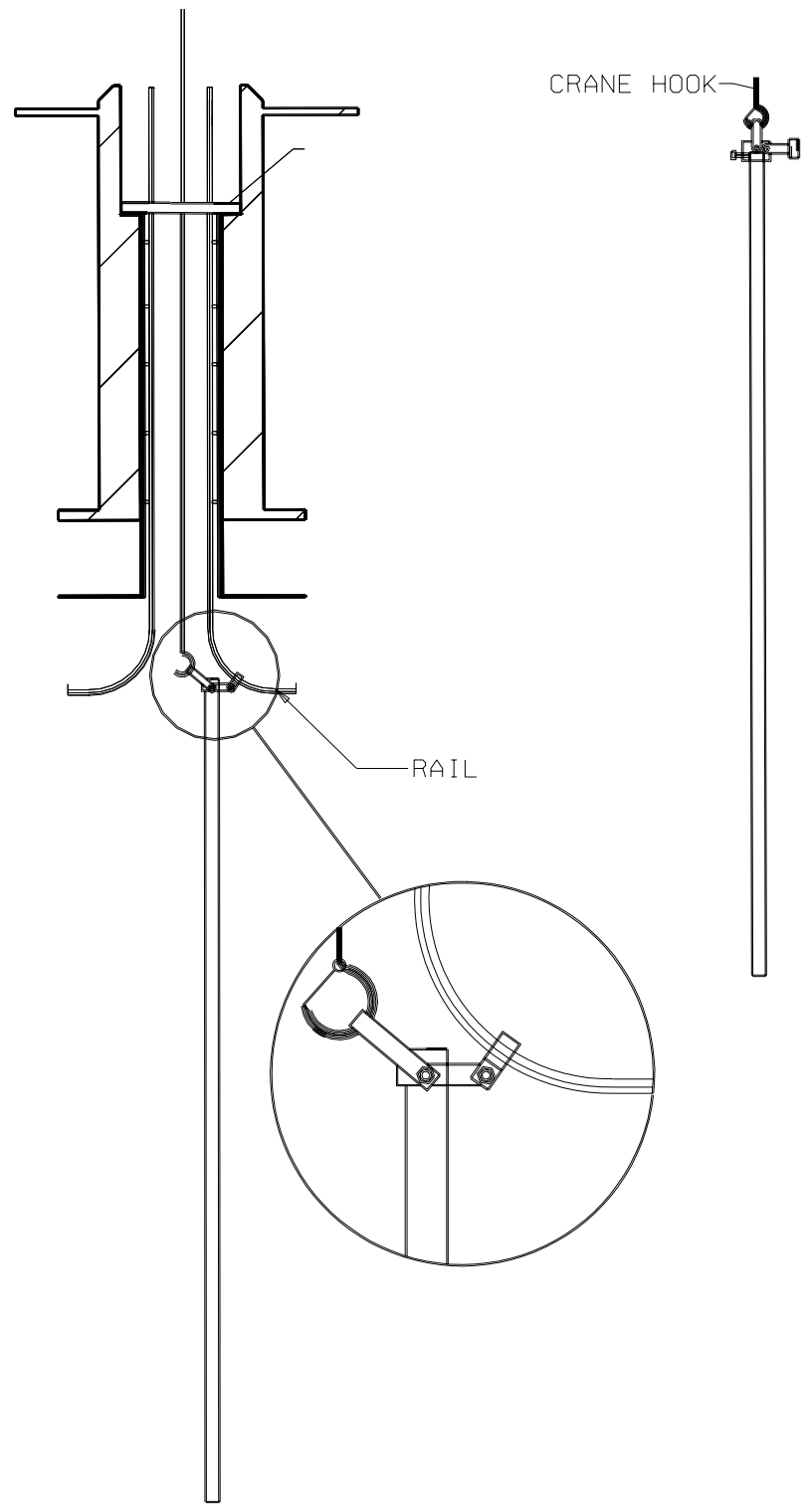

Figure 6: Lowering failed equipment into the tank 
When the returned equipment reaches the end of the curved section of rail, the crane hook de-couples from it as shown in Figure 7. This process is repeated for all sections being stored in the tank.

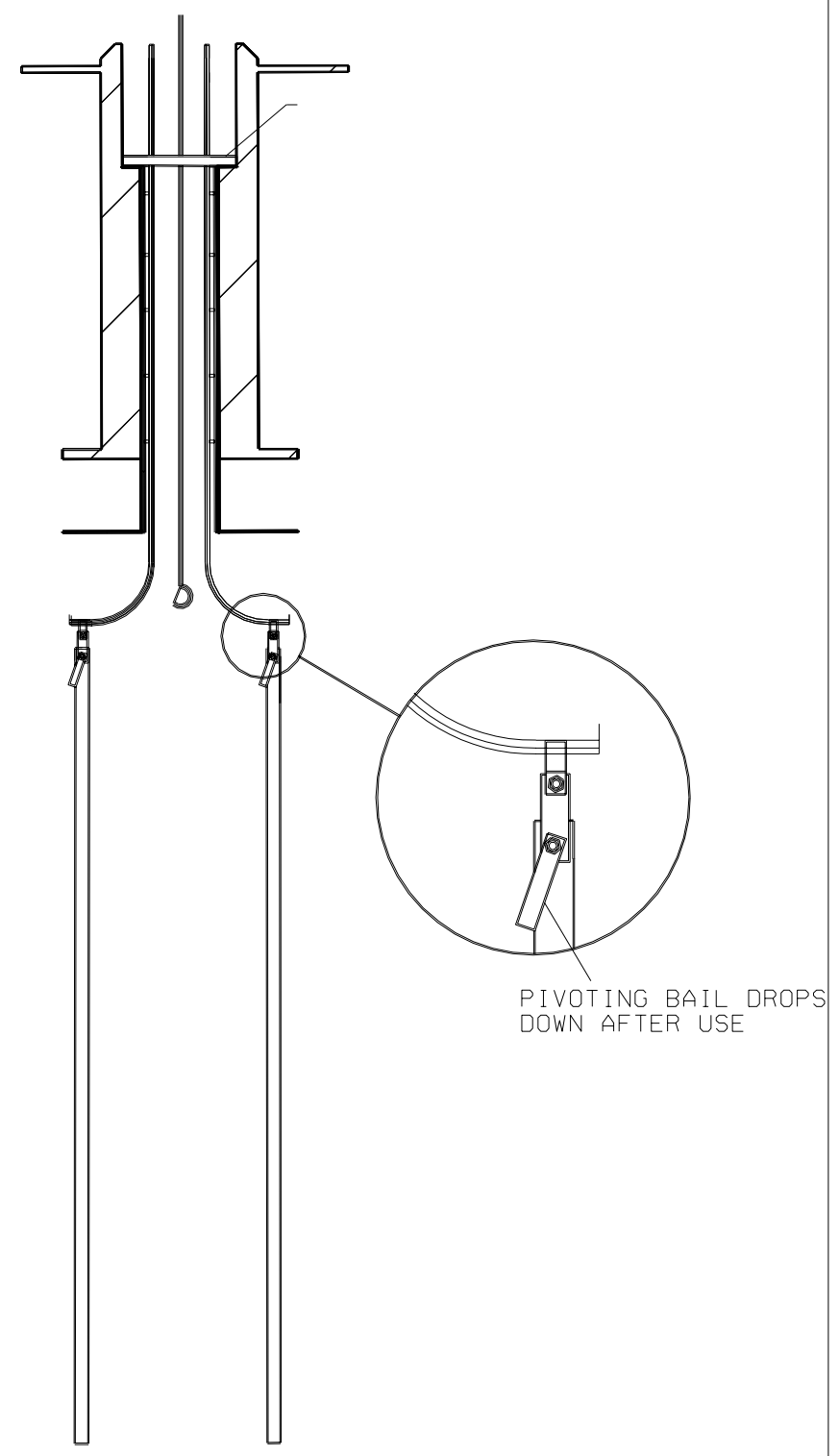

Figure 7: Failed equipment sections hanging inside the tank 
Once the storage process is completed, new process equipment can be lowered into the riser as shown in Figure 8.
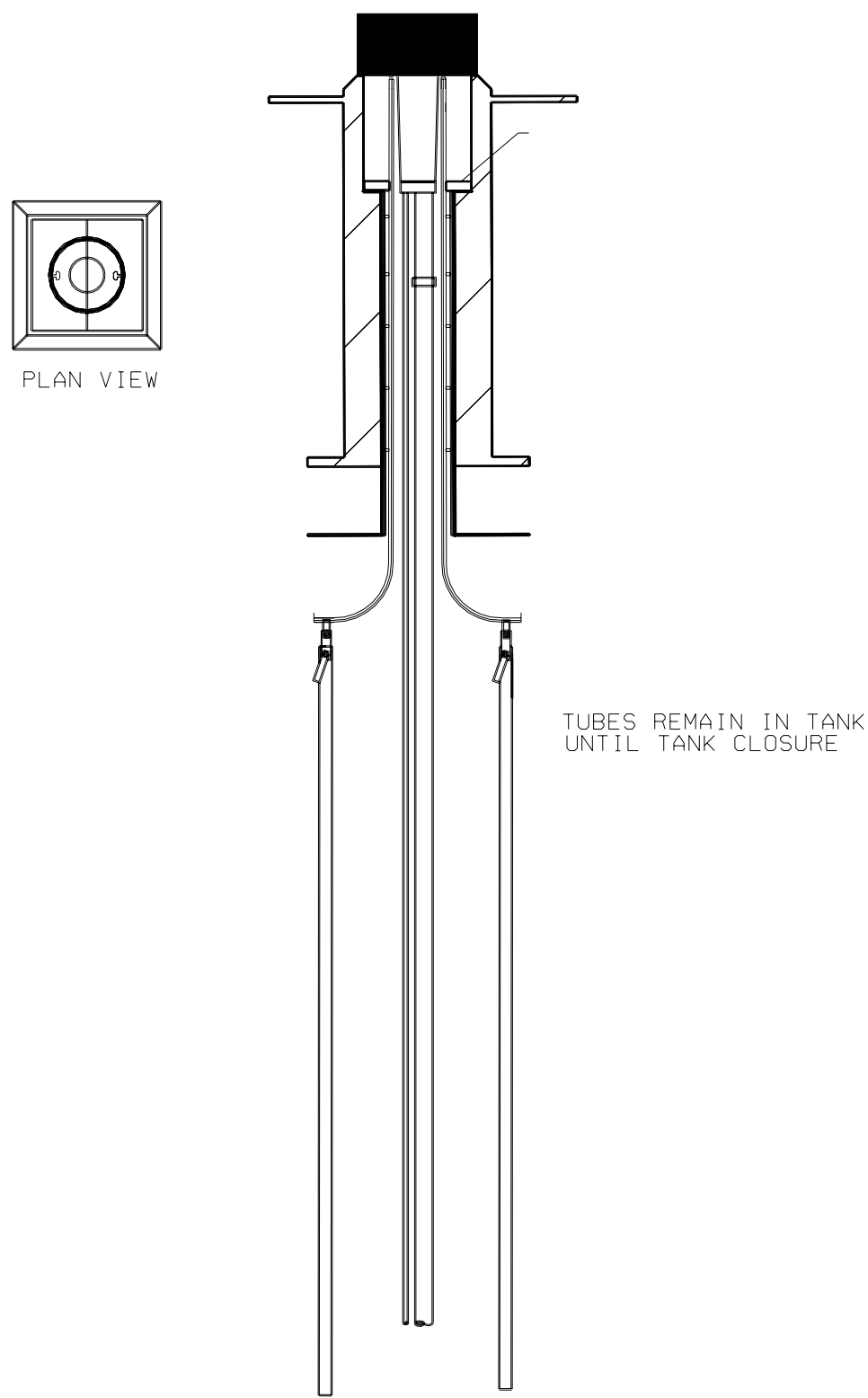

Figure 8: New equipment installed 


\section{CONCLUSION}

The Tank Riser Suspension System would be a great asset to the tank farm operation and is highly recommended. It would allow HLW to store several pieces of equipment and simultaneously use the tank's riser in closure activities. However, working on tank tops and utilizing riser space for hanging multiple components presents significant engineering challenges:

- Designing the insert and rail system

- Designing a universal clamping device or a suite of clamping devices

- Developing a remotely detachable crane hook

Many factors and safety issues must be addressed during the development of design requirements. They include:

- Performing load limit calculations for riser and tank top support of suspended equipment

- Ensuring that suspended equipment won't interfere with tank closure efforts

- Ensuring that suspended equipment won't interfere with existing equipment inside the tanks

\section{ACKNOWLEDGEMENTS}

A special thanks to the following team members for their creativity in providing a solution to a problem in HLW tank closure activities:

Don Pak, SRTC

Jonathan Thomas, HLW/Waste Removal Project

Randall Forty, PE\&CD/Design Execution

Toby Hess, HLW/FTF Waste Removal Project Liaison

Wade Faires, PE\&CD/Structural Mechanics

\section{REFERENCES}

1. Pak, D. J., Eberl, K. R., Baseline Technology Report For the Tank Riser Suspension System (U) WSRC-TR-2001-00441, Savannah River Site, Aiken, SC 29808.

2. Pak, D. J., Eberl, K. R., Functions and Requirements for the Tank Riser Suspension System (U) WSRC-TR-2001-00442, Savannah River Site, Aiken, SC 29808. 


\section{Appendix A}




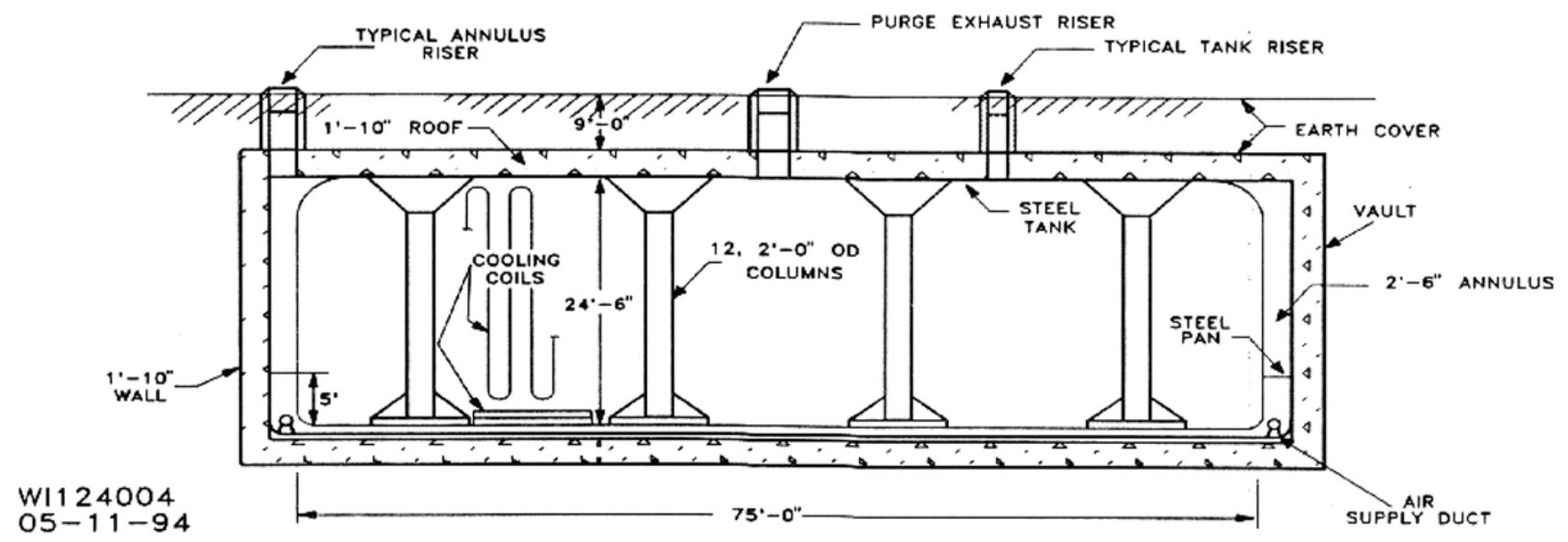

Figure 1A: Type I Waste Tank 


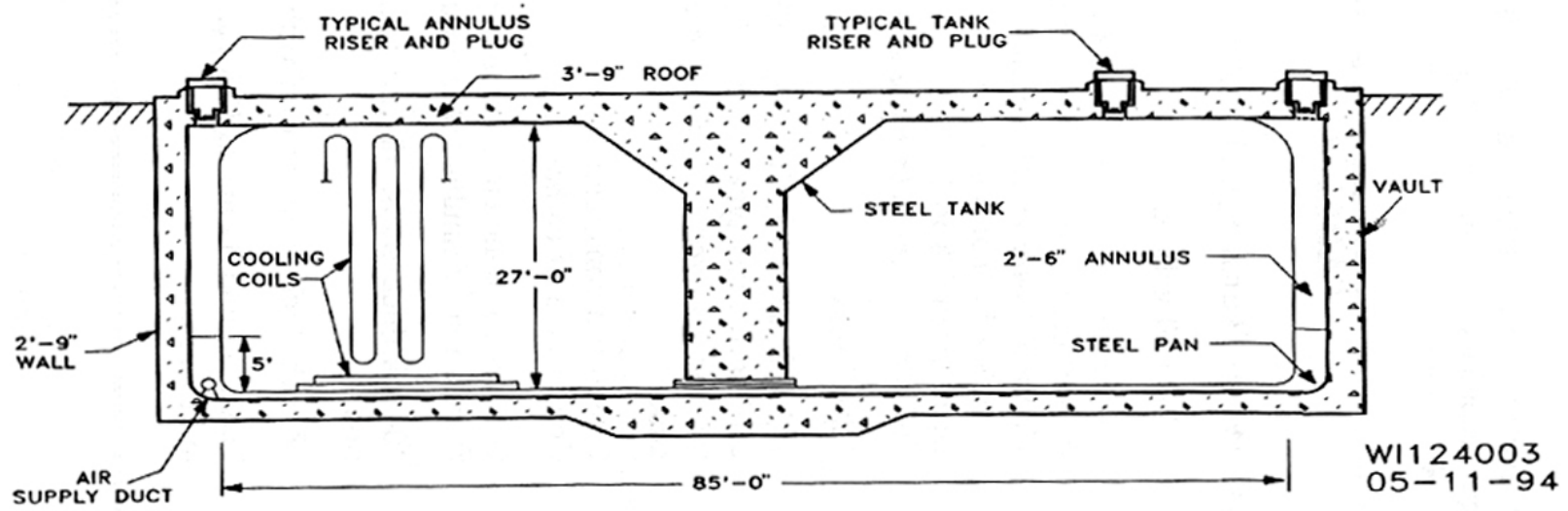

Figure 2A: Type II Waste Tank 


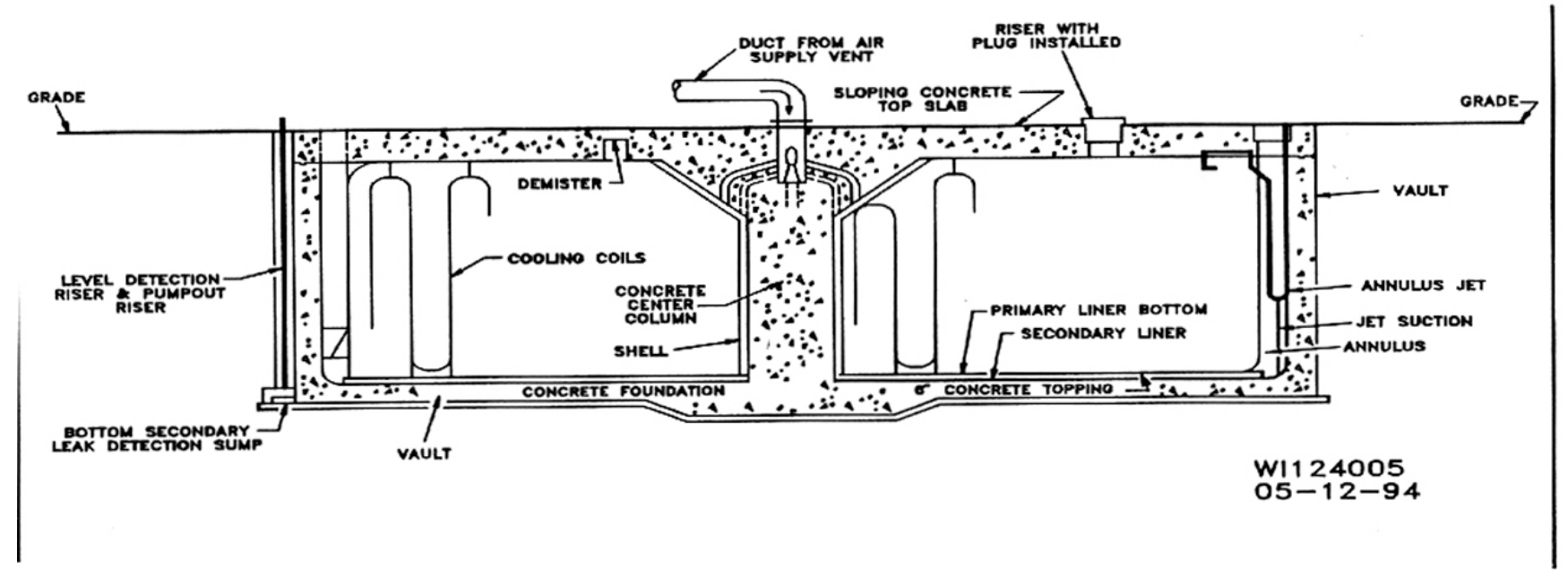

Figure 3A: Type IIIA Waste Tank 


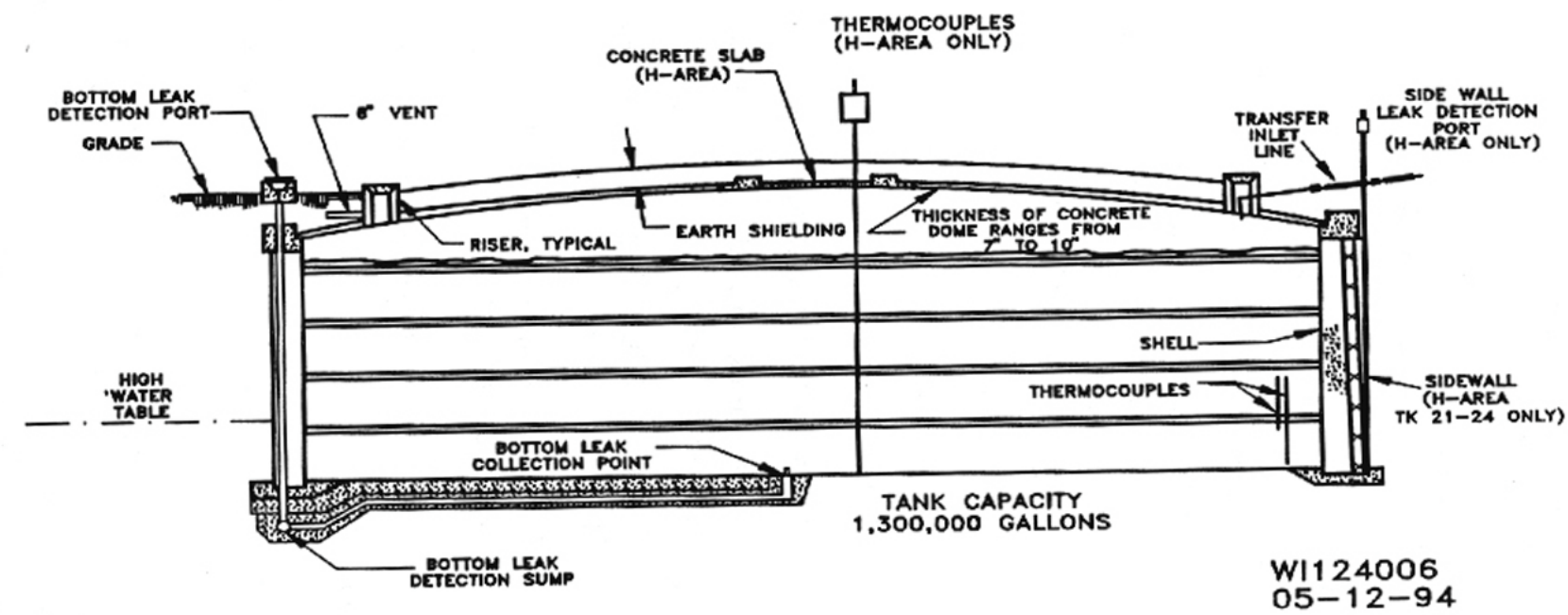

Figure 4A: Type IV Waste Tank 


\section{Appendix B}




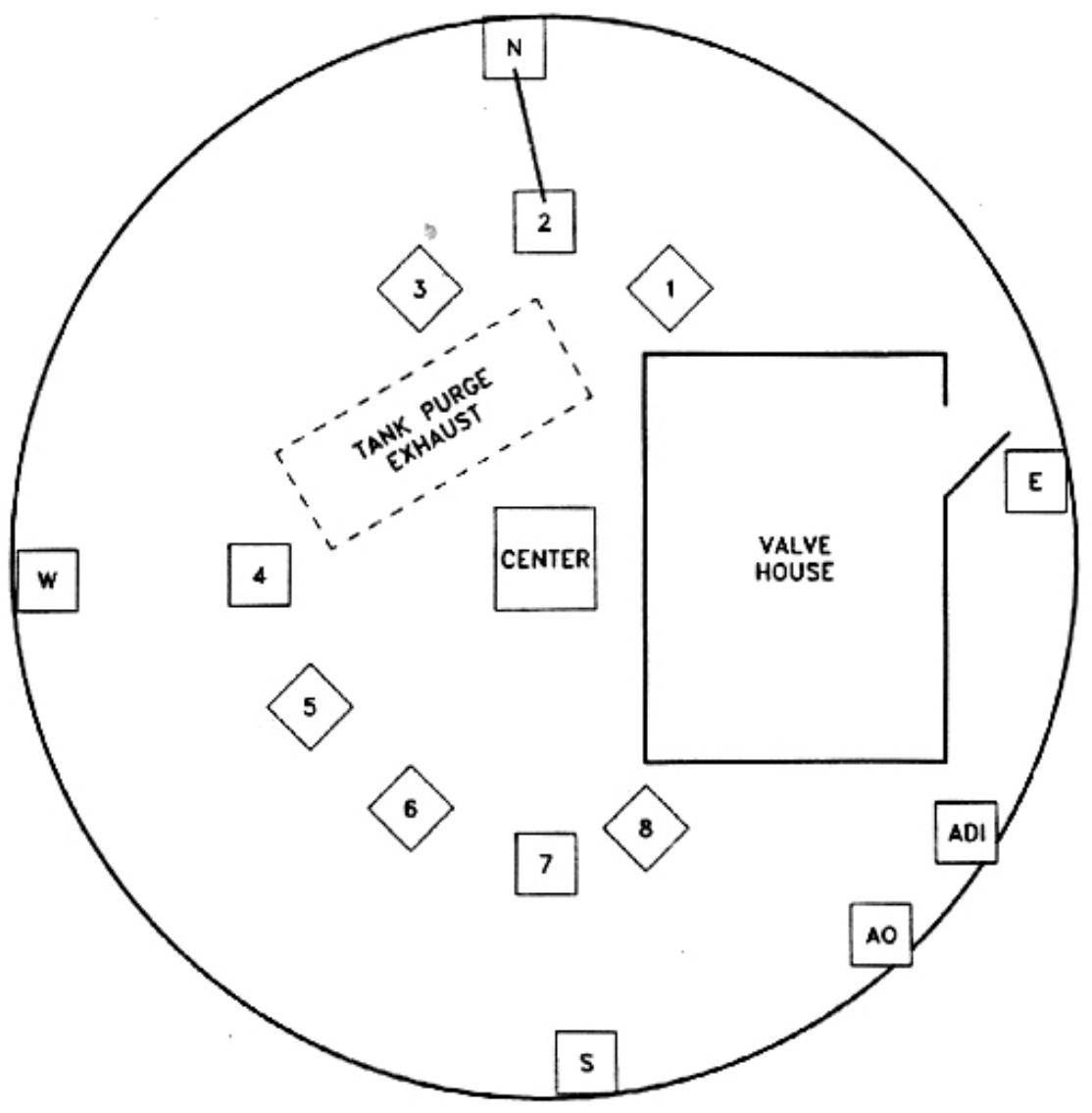

\section{RISER DESCRIPTION}

N ANNULUS JET, CONDUCTIVITY PROBE, STAND PIPE, INSPECTION PORT

$E$ INSPECTION PORT, THERMOCOUPLE WELL, STAND PIPE

S CONDUCTIVITY PROBE, INSPECTION PORT. STAND PIPE

$W$ DIP TUBES, INSPECTION PORT, STAND PIPE, LIQUID LEVEL TRANSMITTER

ADI ANNULUS AIR DEHUMIDIFIER INLET

AO ANNULUS AIR OUTLET

WI124007

$03-28-94$

\section{RISER DESCRIPTION}

CENTER INSPECTION PORT

SPRAY CHAMBER (SLURRY PUMP)

INSPECTION PORT, STEEL TAPE RISER,

ANNULUS JET INLET

JET RISER CONOUCTIVITY PROBE, INSPECTIOON PORT

SPRAY CHAMBER, (SLURRY PUMP)

REEL TAPE, H2 SAMPLE POINT. INSPECTION PORT,

(H\&V)

SPRAY CHAMBER, (SLURRY PUMP) INSPECTION PORT

THERMOCOUPLE WELL, PURGE AIR INLET, SIMULATED VERTICAL COIL, STAND PIPE

Figure 1B: Typical Type I Waste Tank Riser Layout 


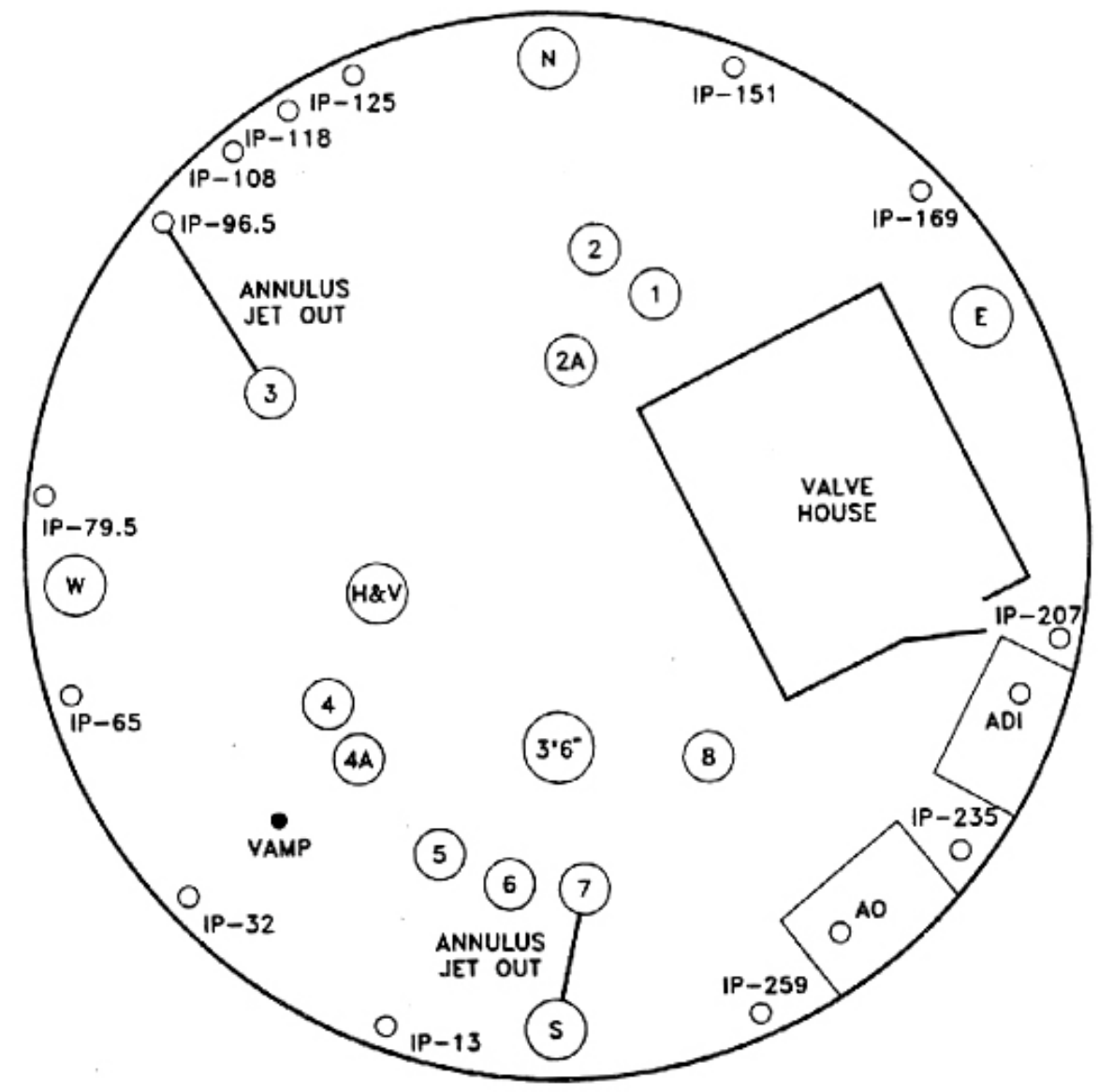

\section{RISER DESCRIPTION}

1 THERMOCOUPLE WELL. INSPECTION PORT, H2 SAMPLE POINT

2 THERMOCOUPLE WELL, INSPECTION PORT

2A STEEL TAPE. THERMOCOUPLE WELL, CAPPED PIPE

3 THERMOCOUPLE WELL, SPARE

4 DIP TUBES, REEL TAPE, CAPPED PIPE

$4 A$ INSPECTION PORT, CAPPED PIPE

5 THERMOCOUPLE WELL, INSPECTION PORT, CAPPED PIPE

6 INSPECIION PORT, CAPPED PIPE

WI124008

$03-28-94$

\section{RISER DESCRIPTION}

ANNULUS JET OUTLET, SPARE

THERMOCOUPLE WEL, PURGE INLET

NECKLACE ALARM (ABANDONED), INSPECTION PORT,

THERMOCOUPLE WELL, CAPPED PIPE

S INSPECTION PORT, ANNULUS JET, 1SO\# STEAM LINE

E DIP TUBES, CONDUCTIVITY PROBE, LIQUID LEVEL

TRANSMITTER

SOIL THEMOCOUPLE, INSPECTION PORT

3'6" THERMOCOUPLE WELL, CAPPED PIPE, DIP TUBES, SPARE

IP INSPECTION PORT

AO ANNULUS AIR OUTLET

ADI ANNULUS DEHUMIDIFIER AIR INLET

Figure 2B: Typical Type II Waste Tank Riser Layout 

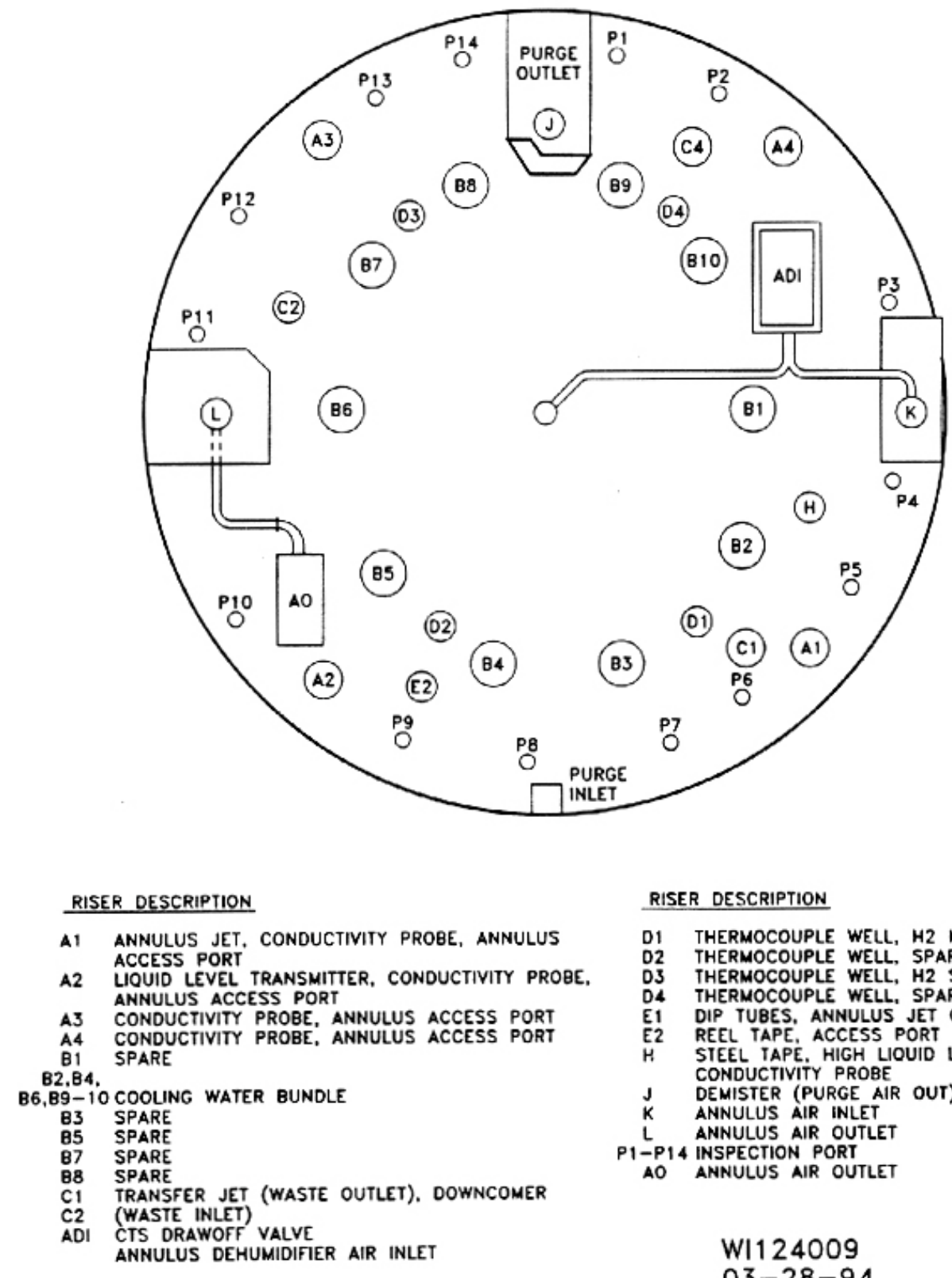

RISER DESCRIPTION

D1 THERMOCOUPLE WELL, H2 MONITOR

D2 THERMOCOUPLE WELL, SPARE PIPE

O3 THERMOCOUPLE WELL, H2 SAMPLE POINT

D4 THERMOCOUPLE WELL, SPARE PIPE

E1 DIP TUBES, ANNULUS JET OUTLET

E1 DIP TUBES, ANNULUS JET

$H$ STEEL TAPE. HIGH LIOUID LEVEL

STEEL TAPE, HIGH LIOU

DEMISTER (PURGE AIR OUT)

$K$ ANNULUS AIR INLET

L ANNULUS AIR OUTLET

P1-P14 INSPECTION PORT

AO ANNULUS AIR OUTLET

WI124009

03-28-94

Figure 3B: Typical Type III Waste Tank Riser Layout 


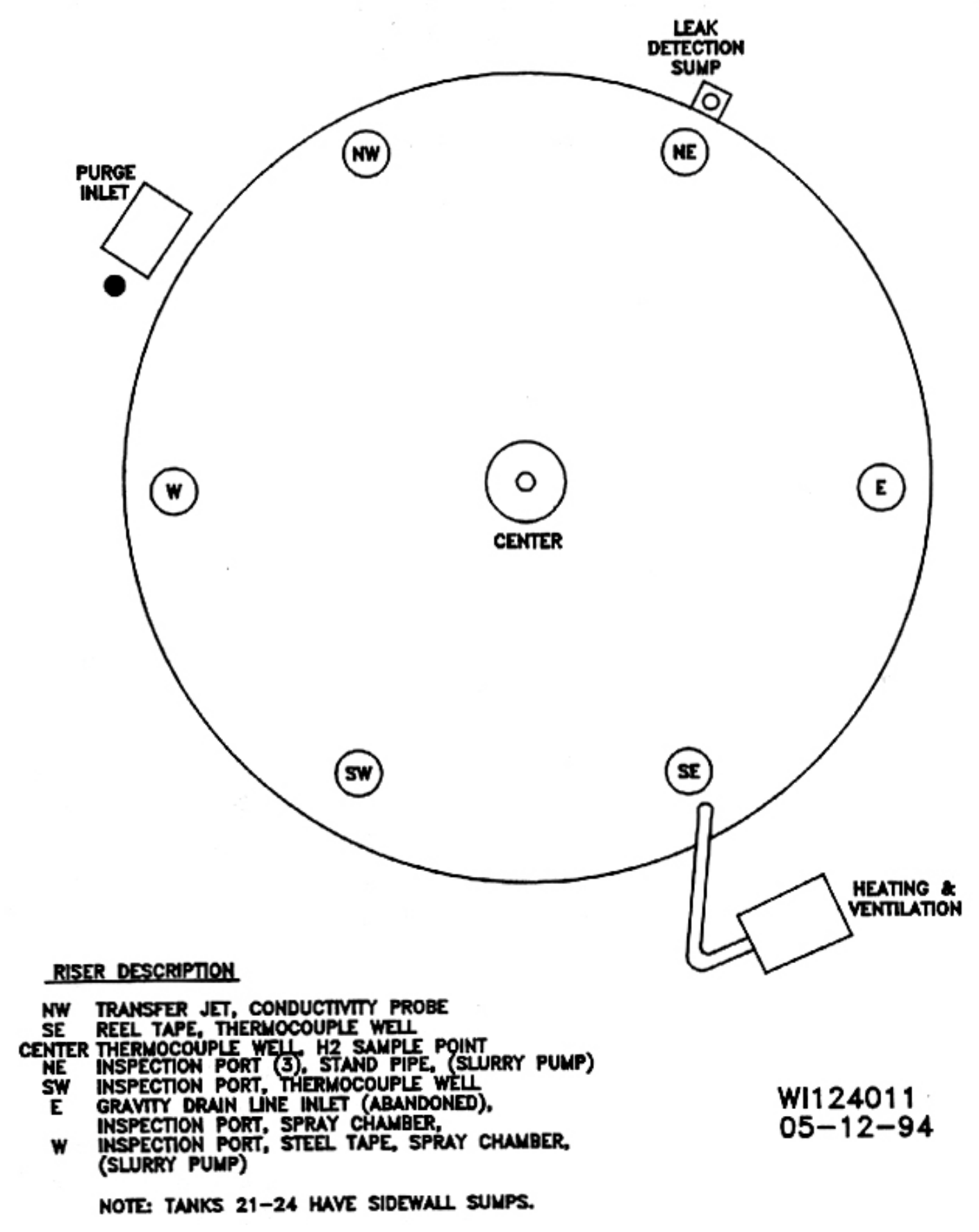

Figure 4B: Typical Type IV Waste Tank Riser Layout 


\section{Appendix C}




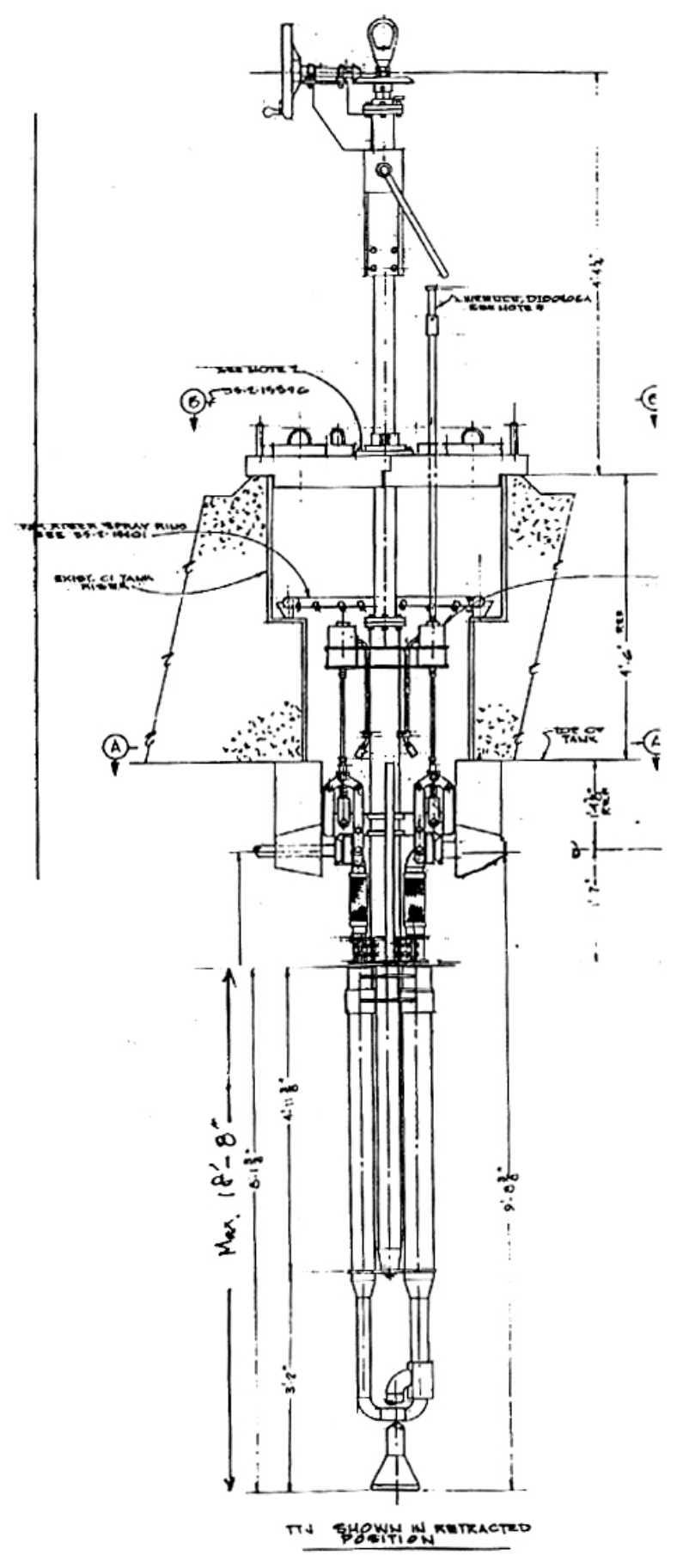

Figure 1C: Telescoping Transfer Jet Pump 


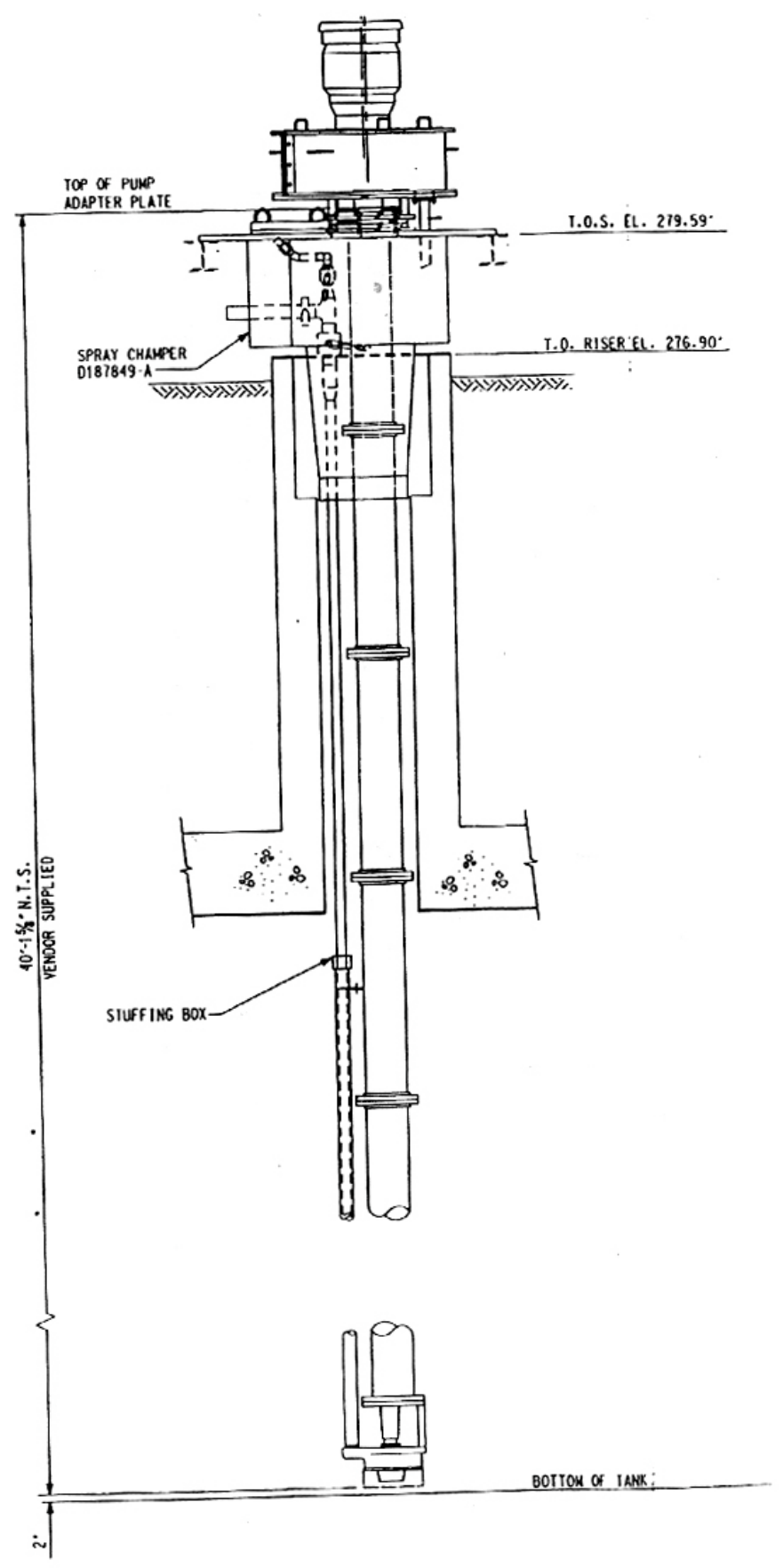

Figure 2C: Telescoping Transfer Pump 


\section{Appendix D}




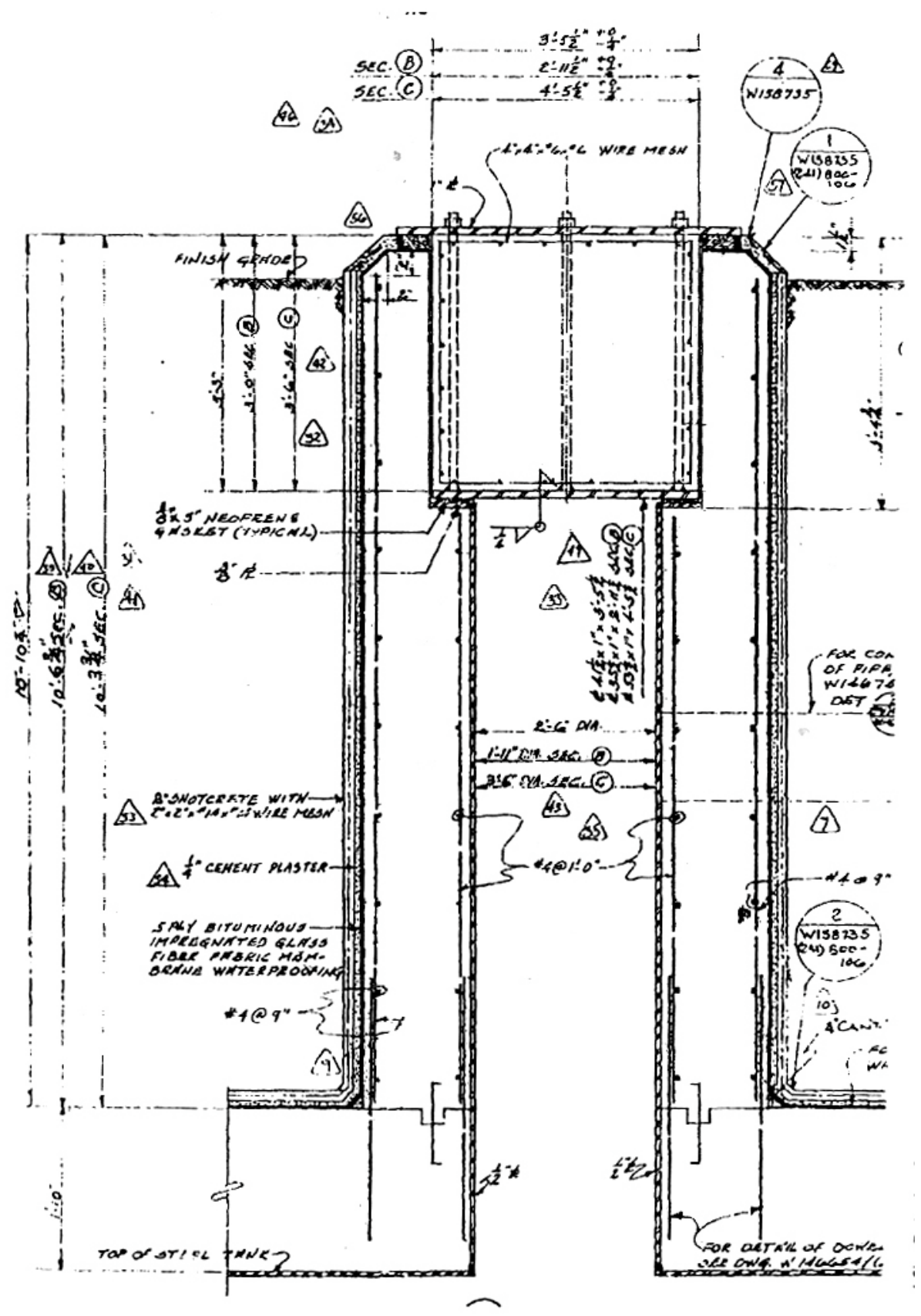

Figure 1D: Typical Type 1 Riser Cross Section 